\title{
Campus Teaching Awards, Academic Year 2010-11
}
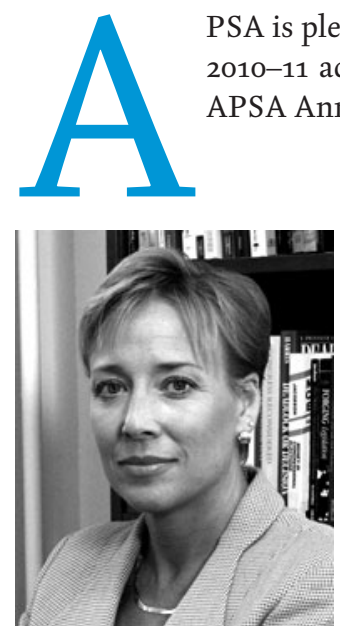

Dr. Lydia M. Andrade, University of the Incarnate Word UIW Presidential Teaching Award

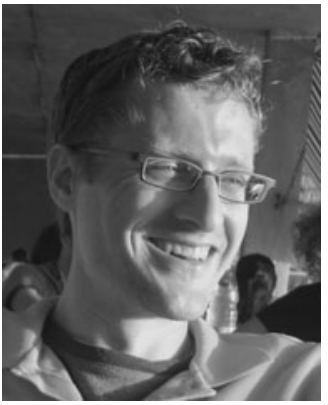

Dr. Daniel Corstange, University of Maryland, College Park

College of Behavioral and Social Sciences' Excellence in Teaching Award

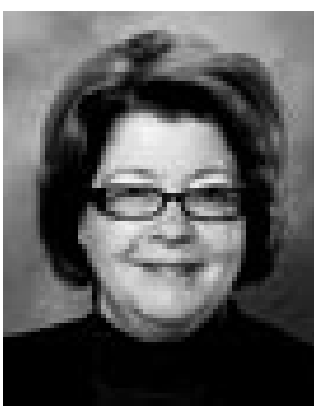

Dr. Kathleen M. Hale,

Auburn University College of Liberal Arts Community and Civic Engagement Award

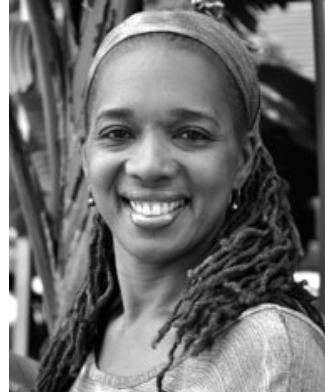

Dr. Lisa Aubrey, Arizona State University

Faculty of the Year Award from the Black and African Coalition and Outstanding Undergraduate Mentor Award

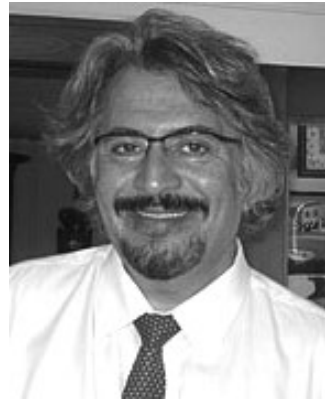

Dr. Alexander Dawoody, Marywood University Professor of the Year Award

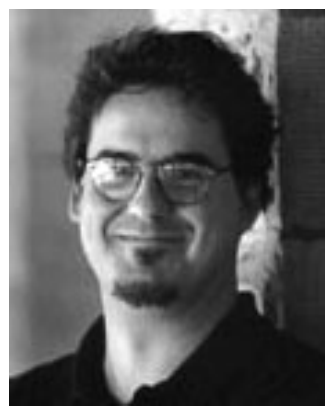

Dr. Ron E. Hassner

University of California, Berkeley

UPSA's Distinguished

Teaching Award

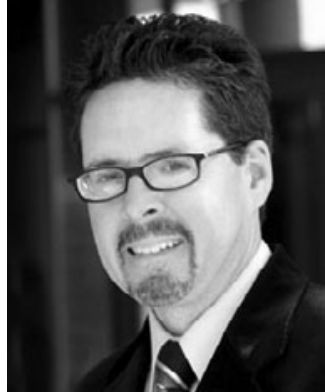

Dr. Rob Baker,

Wittenberg University

Distinguished Teaching Award

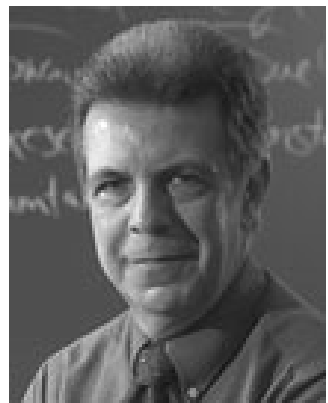

Dr. Robert F. Durant, American University

American University Scholar-Teacher of the Year Award

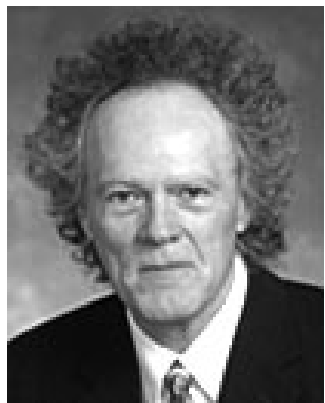

Dr. Kim Quaile Hill

Texas A\&M University The Association of Former Students Distinguished Achievement Award for Teaching

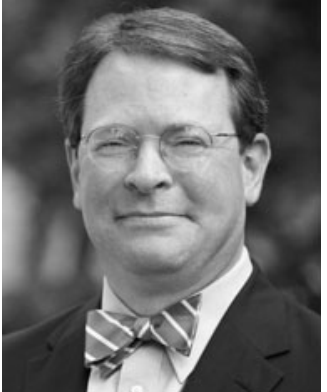

Dr. J. Michael Bitzer, Catawba College Swink Prize and Professorship

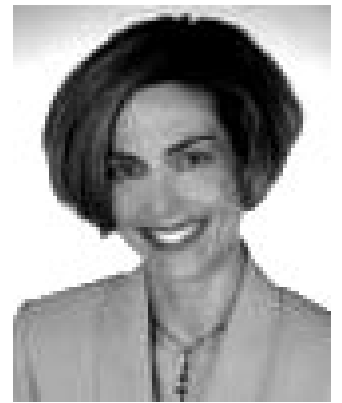

Dr. Victoria A. FarrarMyers, University of Texas Arlington

Inducted into the Academy of Distinguished Teachers

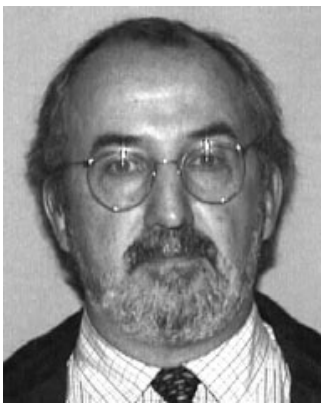

Professor Mark S. Hyde, Providence College Joseph R. Accinno Teaching Award

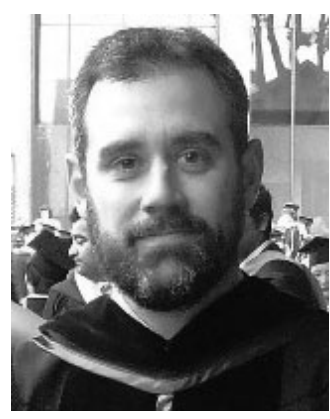

Dr. Michael Butler, Clark University The 2010-2011 Outstanding Teacher Award

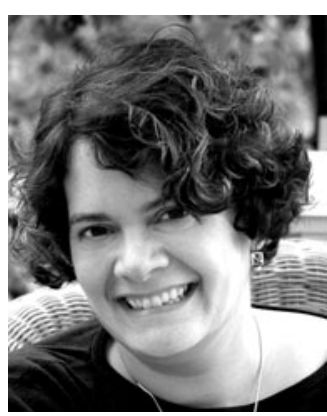

Dr. Lilly J. Goren, Carroll University Benjamin F. Richason, Jr. Faculty Award

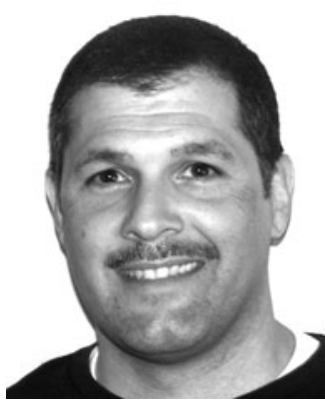

Dr. Michael Infranco

Washington State

University

Pi Sigma Alpha

Outstanding Political

Science Instructor 


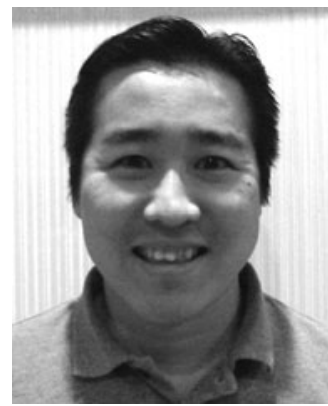

Dr. Nori Katagiri, Air War College

Air War College Faculty Award for Teaching Excellence

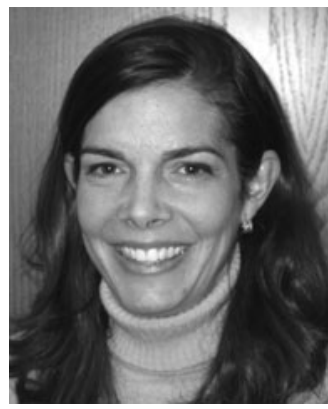

Dr. Lauren MacLean, Indiana University Bloomington

Trustees Teaching Award

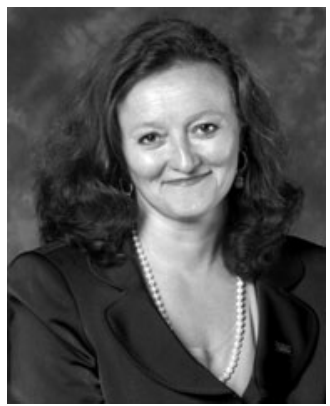

Dr. Kimi Lynn King, University of North Texas University Distinguished Teaching Professor

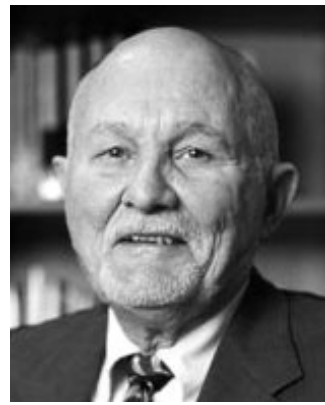

Dr. Laurel A. Mayer, Sinclair Community College

NISOD Teaching Excellence Award

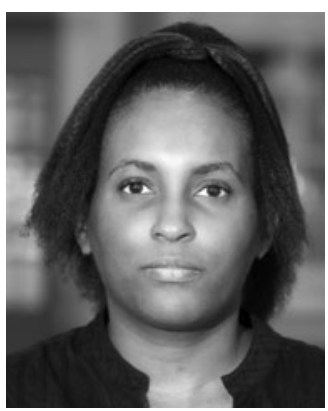

Dr. Barbara Patrick, Mississippi State University 2011 Arts and Sciences Teaching Award

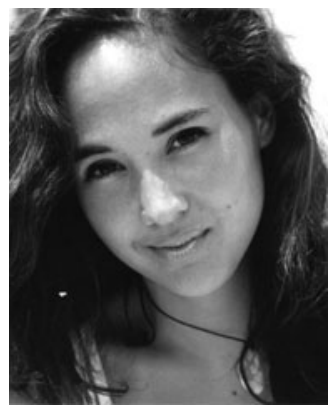

Nina Kollars, The Ohio

State University

College of Arts and Sciences

Outstanding Graduate

Teaching Award

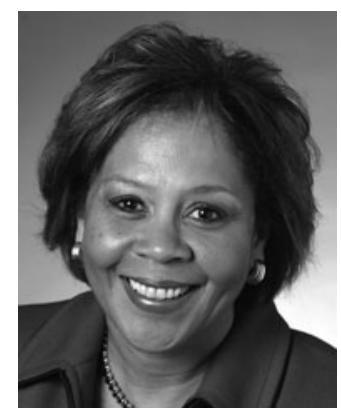

Dr. Paula McClain,

Duke University

Graduate Dean's Award for

Excellence in Mentoring and 2010 Dean's Award for Excellence in Mentoring

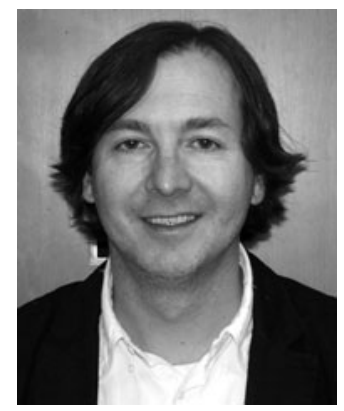

Dr. J. Mitchell Pickerill,

Washington State University Pi Sigma Alpha

Outstanding Political Science Professor

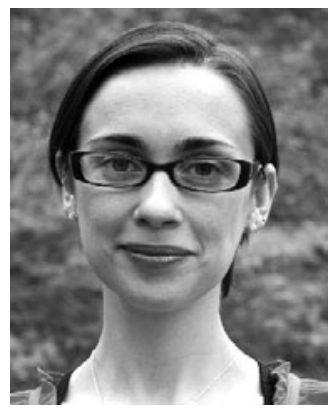

Dr. Yanna Krupnikov, Indiana University Bloomington Trustees Teaching Award

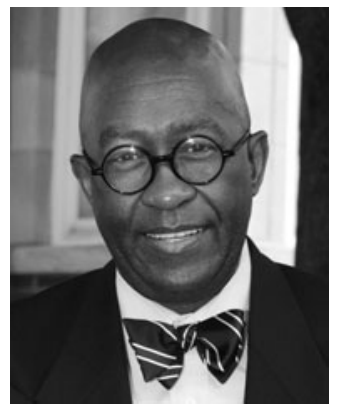

Professor K.C. Morrison, Mississippi State University

2011 Mississippi Black Educator of the Year

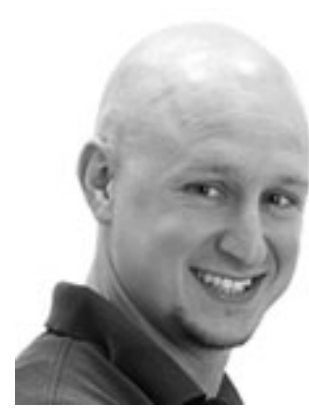

Dr. Erik T. Rankin,

Illinois State University College of Arts and Sciences Excellence Award for Outstanding Teaching Award-AP for 2011

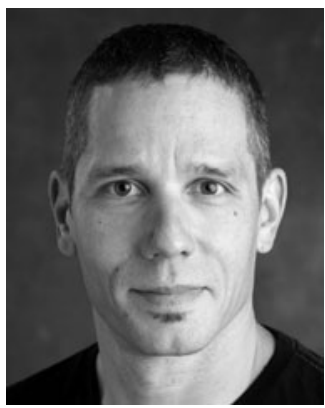

Dr. Mika LaVaque-Manty, University of Michigan Arthur F. Thurnau Professorship

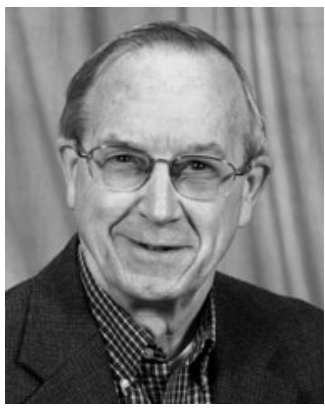

Professor Richard G. Niemi, University of Rochester

William H. Riker University Award for Graduate Teaching

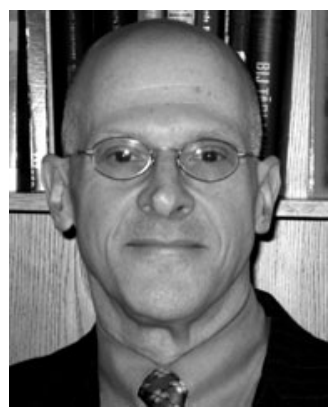

Dr. Raymond Rosenfeld, Eastern Michigan University Alumni Association Teaching Excellence Award 


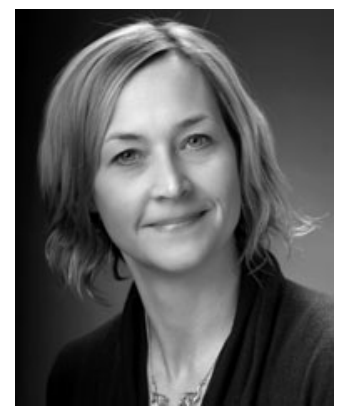

Dr. Sara L. Rushing,

Montana State University College of Letters and Science Outstanding Teaching Award

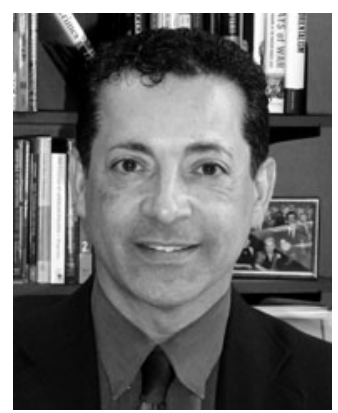

Dr. Houman Sadri,

University of Central

Florida

UCF Scholarship of

Teaching and Learning (SoTL) Award and UCF

Teaching Incentive Program Award

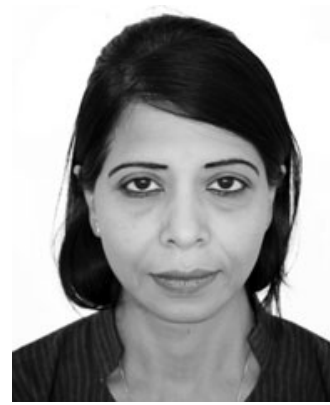

Dr. Indira Sinha, College of Commerce

Glory of India Award, International Achievers' Award, Shiksha Ratna Puraskar and Indian Achievers' Award

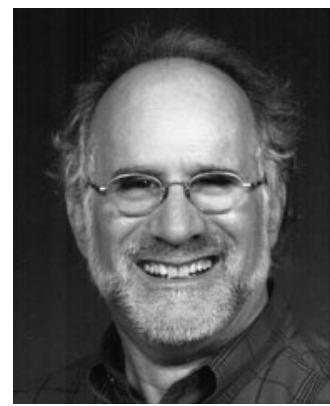

Dr. Kenneth D. Wald, University of Florida Teacher-Scholar Award

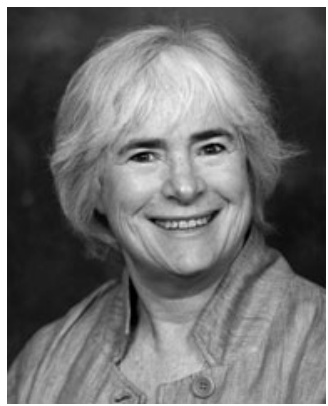

Professor Arlene W.

Saxonhouse, University of Michigan

Tronstein Prize

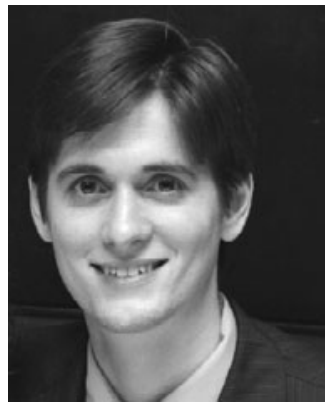

Dr. Jason Sorens,

University at Buffalo, SUNY

Lisa Hertel Outstanding Professor Award

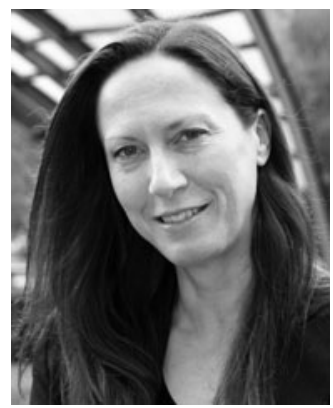

Dr. Mary Walsh,

University of Canberra, Australia

Vice-Chancellor's Award for Teaching Excellence and the Unit Satisfaction Survey Recognition Award

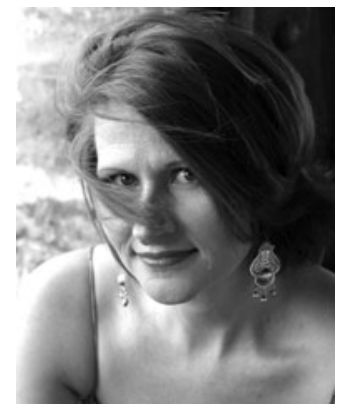

Dr. Jillian M. Schwedler, University of Massachusetts, Amherst University Distinguished Teaching Award

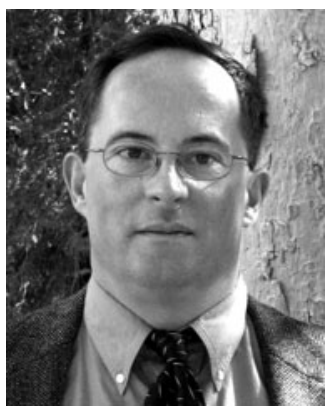

Professor John T. Scott University of California, Davis Distinguished Teaching Award for Graduate and Professional Teaching

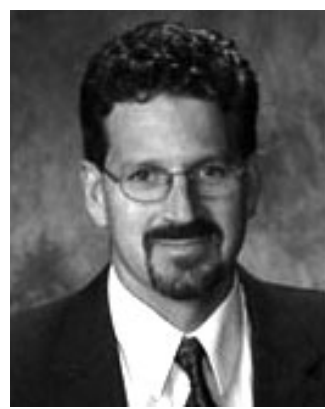

Dr. Brendon Swedlow, Northern Illinois

University

Excellence in Undergraduate Teaching Award

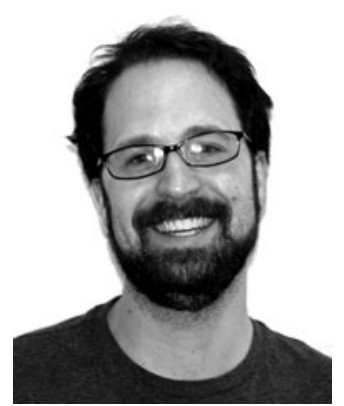

Dr. Matt Weidenfeld, Washington State University Pi Sigma Alpha Outstanding Political Science Professor

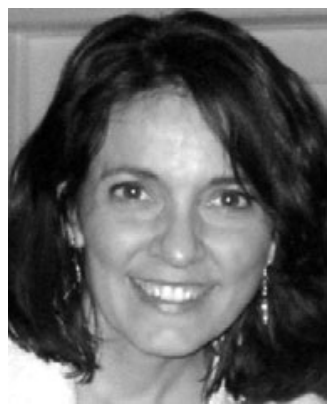

Dr. Jeanne Zaino, Iona College 2011 Presidential Teaching Scholar, Iona College 


\section{CAMPUS TEACHING AWARD RECIPIENTS, CONTINUED}

Dr. Scott Abernathy, University of Minnesota Morse-Alumni Award for Outstanding Contributions to Undergraduate Education

Dr. Benjamin O. Arah, Bowie State University College of Arts and Science 2011 Extra-Miler Award and Outstanding Faculty Service to the Department

Dr. Matthew Beckmann, University of California, Irvine Outstanding Faculty Mentoring Award

Professor Jeff Borg, Front Range Community College Master Teacher

Craig Borowiak, Haverford College The Lindback Award for Distinguished Teaching

Bryan Buford, Auburn University College of Liberal Arts Instructional Excellence Award

Dr. Christopher K. Butler, University of New Mexico The University of New Mexico College of Arts and Sciences Award for Teaching Excellence

Dr. Rachael V. Cobb, Suffolk University Outstanding College of Arts and Sciences Faculty of the Year

Juvenal J. Cortes, University of Southern California Teaching Assistant Fellow

Dr. Michelle D. Deardorff, Jackson State University Department of Political Science Trailblazer Award for Outstanding Faculty

Dr. Debra DeLaet, Drake University Arts and Sciences Teacher of the Year
Dr. Todd A. Eisenstadt, American University 2010 Teaching with Research Award

Dr. Mark Haas, Duquesne University Omicron Delta Kappa Teacher of the Year AwardHonorable Mention

Tracy Harbin, St. John Fisher College 2011 Academic Advising Award

Dr. Heather L. Hawn, University of South Carolina

Education Foundation Outstanding Graduate Student Teaching Award

Dr. Richard Holtzman, Bryant University Student Senate Choice Award for Faculty Cooperation and Support

Dr. Marc Morjé Howard, Georgetown University 2010-11 Lepgold Award

Wendy L. Johnston, SUNY Adirondack Community College SUNY Adirondack 2011 President's Award for Excellence in Teaching-Junior Faculty

Dr. Joseph F. Jozwiak, Jr., Texas A\&M UniversityCorpus Christi College of Liberal Arts Excellence in Teaching Award

Dr. Allison F. Kingsley, University of Vermont Undergraduate Teacher of the Year

Dr. Ari Kohen, University of Nebraska-Lincoln College of Arts and Sciences Distinguished Teaching Award

Professor Robin Kolodny, Temple University
Lindback Award for Distinguished Teaching

Dr. Jonathan Krasno, Binghamton University SUNY Chancellor's Award for Excellence in Teaching

Dr. Douglas L. Kriner, Boston University Gitner Award for Distinguished Teaching

Dr. Isis I. Leslie, Texas Tech

University

Phi Beta Kappa Teaching Award

Dr. William Lowry, Washington University Distinguished Faculty Award

Professor Jacques Mangala, Grand Valley State

University

Pew Teaching Excellence

Award

Dr. Melanie Manion, University of Wisconsin Madison Chancellor's Distinguished Teaching Award

Dr. Sarah Marusek, University of Hawaii, Hilo 2011 Frances Davis Award for Excellence in Undergraduate Teaching

Dr. Jonathan Mercer, University of Washington Distinguished Teaching Award

Dr. Robert G. Moser, University of Texas Silver Spurs Teaching Fellowship Award

Dr. William Munro, Illinois Wesleyan University Kemp Award for Teaching Excellence

Dr. Smita A. Rahman, DePauw University Exemplary Teacher Award, 2010-2011
Dr. Laurie A. Rhodebeck, University of Louisville Award for Instructional Development

Professor Caesar D. Sereseres, University of California, Irvine Professor of the Year

Dr. Steve Snow, Wagner College Award for Exceptional Performance in Area of Teaching

Professor Dorothy Solinger, University of California, Irvine Outstanding Mentoring Award

Dr. Marek Steedman, University of Southern Mississippi 2010 Humanities Teacher Award

Jerrold Waltman, Baylor University Robert Reid Award for Distinguished Undergraduate Teaching

Dr. Robert Webking, University of Texas at El Paso University of Texas Regents Outstanding Teaching Award

Dr. David L. Weiden, Indiana University-Purdue University Indianapolis Indiana University Trustees Teaching Award

Dr. Krista E. Wiegand, Georgia Southern University College of Liberal Arts and Social Sciences Award for Excellence in Research, Teaching, and Service

Dr. Bruce Wilson, University of Central Florida Teaching Incentive Program Award 


\section{American Political Science Association}

\section{The APSA Distinguished Teaching Award}

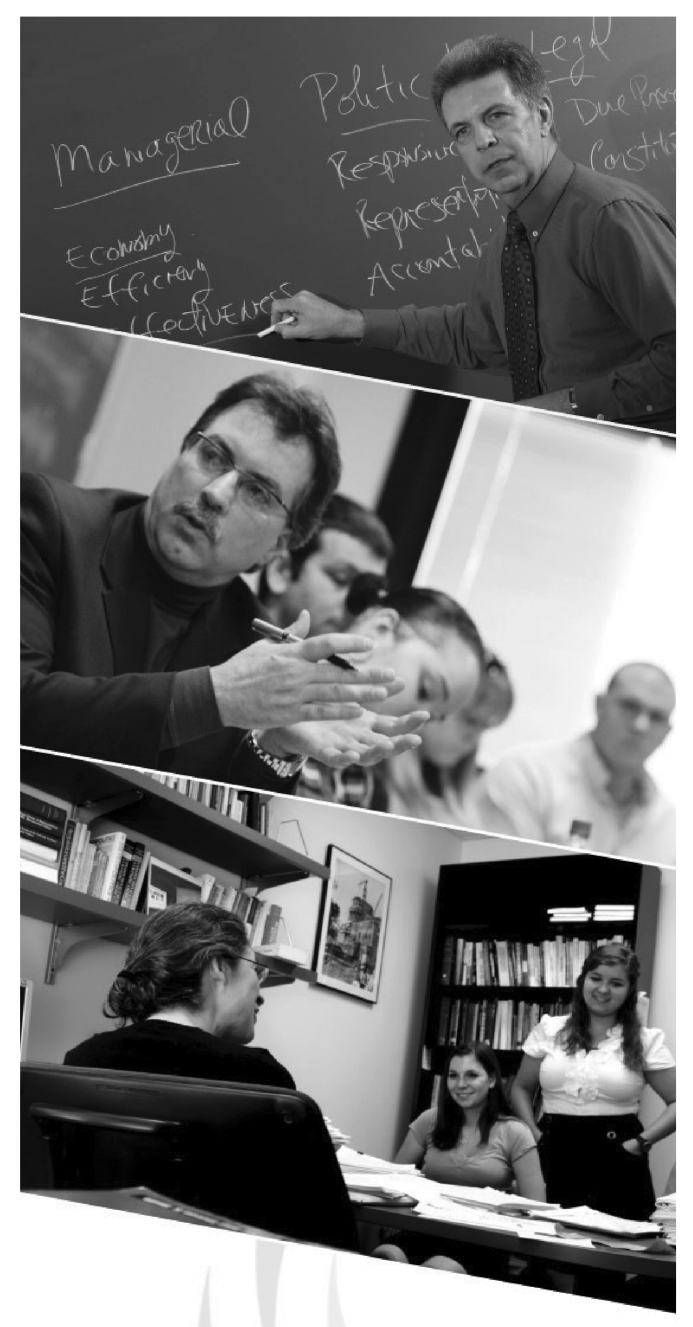

"By helping my students understand that group differences still matter in America, I am preparing them to live in our increasingly diverse society and forge solutions that will draw us closer together."

$$
\begin{aligned}
& \text { - Alvin Tillery } \\
& \text { Rutgers University }
\end{aligned}
$$

For more than 100 years, APSA has recognized excellence across the discipline. Its awards for scholarship and service are among the most distinguished in the discipline. Now the association has a formal means to recognize excellence in political science education.

We are proud to announce the establishment of the first ever APSA Distinguished Teaching Award.

The award will honor the outstanding contriutions of an individual to undergraduate and/or graduate teaching of political science at an institution of higher learning. It will credit accomplishments aimed at enhancing teaching in the profession and it will recognize contriutions spanning years or an entire career.

\section{Call for Nominations:}

Nominations for the first award open on October 15, 2011. The first award will be given during the 2012 Annual Meeting in New Orleans, Louisiana. Nominations from departments, chairs, colleagues, and self-nominations are welcome.

\section{Learn more at www.apsanet.org/teachingaward}

\footnotetext{
For any questions or concerns regarding the award, please email APSATeachingAward@apsanet.org or call APSA's National Office at 202-483-2512
}

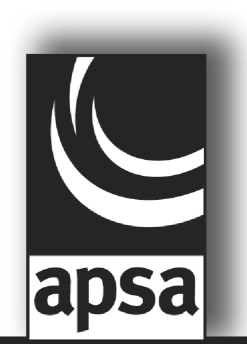




\section{American Political Science Association}

\section{EDUCATION, PROFESSIONAL, \& DIVERSITY INITIATIVES}

The American Political Science Association (founded in 1903) is a membership association that provides resources for research, networking, and professional development to its 15,000 members in the U.S. and abroad in the political science discipline. The APSA Office of Education, Professional and Minority Initiatives offers resources to students and faculty alike. APSA is dedicated to the promotion of excellence in the areas of education, professional development, and diversity.

Please share the following list of APSA programs with your departments, colleagues, and students and visit www.apsanet.org/education for more information.

\section{Education Programs and Initiatives}

One key component of APSA's mission is to support political science education and to promote high quality teaching and education about politics and government:

- Graduate Student Outreach

- Grants, Funding and Fellowship Resources

- Political Science Education Organized Section

- Committee on Civic Education and Engagement

- Teaching and Learning Conference

\section{Professional Development Programs}

APSA seeks to enhance the professional development of its practitioners by providing academic and non-academic opportunities for members:

- APSA Mentoring Initiative

- APSA Annual Meeting

- Undergraduate/Graduate Student Membership

- eJobs: APSA's online job database

- eJobs Annual Meeting Placement Interview Service

- Career Resources and pamphlets

- Job Candidate Questions to Ask

- Professional networking tools and newsletters

\section{APSA Minority and Diversity Initiatives}

Part of the APSA mission is to enhance diversity in the political science discipline. To that end, APSA provides several programs and resources to assist students from underrepresented groups who are considering an advanced degree in political science.

- APSA Minority Fellows Program (MFP) (seniors or MA students)

- Ralph Bunche Summer Institute (RBSI) (juniors)

- Minority Student Recruitment Project (MSRP)

- APSA Mentoring Initiative

\section{For more information, visit www.apsanet.org or contactepd@apsanet.org.}

